\title{
Plant Growth-Promoting Bacteria Associated with the Nests of the Seed- Harvester Ant, Trichomyrmex Scabriceps
}

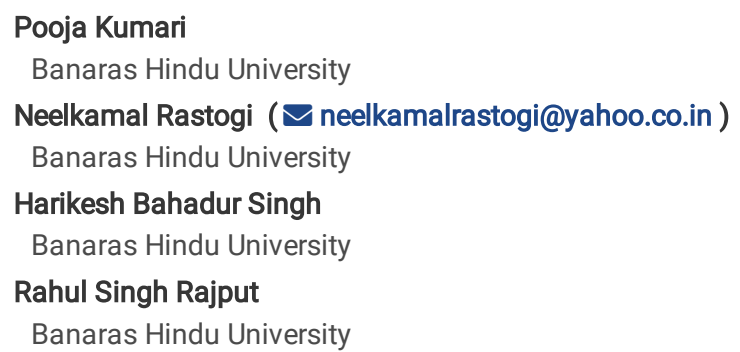

\section{Research Article}

Keywords: Soil fertility, biocontrol, Sclerotium rolfsii, Bacillus, Azotobacter chrococcum

Posted Date: January 6th, 2022

DOI: https://doi.org/10.21203/rs.3.rs-1224812/v1

License: (c) (i) This work is licensed under a Creative Commons Attribution 4.0 International License. Read Full License 


\section{Abstract}

Colonies of seed harvester ants are commonly found in semiarid and arid areas of the world and have been studied for their seed dispersal behaviour. The present study focused on the bacteria associated with the nests of the harvester ant, Trichomyrmex scabriceps, and reveals that ant colonies link the aboveground resources with the belowground microbial communities as they accumulate organic debris in the close vicinity of their nests via their ecosystem engineering activities. Soil samples were collected from the nest chambers and the external debris piles of $T$. scabriceps colonies, located in managed ecosystems. The nest soil-associated bacteria were examined for their plant growth-promoting abilities via biochemical assays including phosphate solubilization, Indole acetic acid production, siderophore production and physiological assays including biocontrol potential against the soil pathogen, Sclerotium rolfsii. More than $60 \%$ of bacteria isolated from the ant nest-associated soil displayed plant-growth promoting ability. Bacillus sp., Azotobactersp., Klebsiella sp., Comamonas sp., Tsukamurella sp., and Pseudoxanthomonax sp., demonstrated significantly high levels of gnotobiotic growth of the treated chickpea plants. The activities of phenylalanine ammonia-lyase and peroxidase enzymes were higher in plant growth-promoting bacteria treated and pathogen inoculated plants as compared to the control plants lacking the bacteria. Since T. scabriceps colonies often make their nests in the compact soil of unpaved paths of agroecosystems and gardens, these bacteria can act as highly effective biofertilizers and promote growth of the cultivated plants by increasing soil fertility and disease resistance attributes of the plant.

\section{Introduction}

Although recent studies have documented a high diversity of agroecosystem-inhabiting ants and reported the significant role of the ecosystemengineering activities of ant colonies in soil fertility enhancement [1,2], only scanty information is available on the association of ant colonies with plant growth-promoting bacteria (PGPB) [3]

The beneficial free-living bacteria present in soil that colonize the rhizosphere, the rhizoplane (root surface), or the plant root itself (within radicular tissues) and promote plant growth, are referred to as PGPB [4]. These PGPB enhance plant growth via production of phytohormones, such as indole acetic acid (IAA), gibberlin, and cytokinin [5]. The principal hormone IAA, produced by PGPB is responsible for physiological processes, such as cell division, root, and shoot development [6]. The insoluble phosphates in soil are also made available to the plants by phosphate-solubilizing microorganisms by the processes of acidification, chelation, and exchange reactions [7, 8]. Also, the secondary metabolites known as siderophores released from PGPB can chelate $\mathrm{Fe}^{3+}$ (ferric) ions from the soil with higher affinity and provide this complex to the plants [9]. Many plant growthpromoting (PGP) microbes also play an important role in suppressing phytopathogens, and this activity may be mediated via direct and/or indirect mechanisms [10,11]. While the direct mechanisms involve the production of siderophores, antibiotic and lytic enzymes [12, 13], the indirect mechanisms involve induction of local and systemic resistance against phytopathogens [14] by production of phenols such as phenylalanine ammonia-lyase (PAL), and peroxidase $\left(\mathrm{PO}_{\mathrm{X}}\right)$ which play an important role in plant disease resistance [15]. The use of these microbe-based biofertilizers helps in reducing the use of chemical fertilizers, improves soil fertility and contributes to enhanced plant productivity [16].

Enriched microbiomes documented to occur within ant nests and the surrounding areas are often found to be distinct from those found in bare soil, indicating the role of ant colonies in influencing soil microbial communities [17]. The richness and diversity of soil microbes are known to be affected by the differences in the organic amendments added to the soil [18]. Hence, the availability of substrates favored by PGPB within the nest chambers and in the external debris pile may be one possible reason for the reported PGP attributes of ant nest debris soil [1, 2]. Ant nests are characterized by the abundance of organic matter brought to the nests by the returning foragers as food for the colony members [19]. While the fecal matter is often deposited in fecal patches in specific locations within the nest [20], the uneaten matter is usually discarded at the external refuse piles. Under experimental field conditions, the yield of crop plants has been found to be significantly enhanced when grown in the nest debris pile soil of Pheidole latinoda, which preferentially colonizes cultivated areas [19,2]. A meta-analysis by Offenberg and Damgaard, [21] indicates that ants may also be involved in the reduction of pathogen loads of the visited plants.

Many ground-nesting ant species, such as the seed harvester ants, construct extensively modified galleries in their nests, forage on the seeds of their preferred plant species and accumulate a huge amount of organic debris in the close vicinity of their nests [22]. Recent studies reveal that both the nest chambers as well as the external refuse piles of plant-visiting, Camponotus compressus colonies harbor many PGP microbes [3]. Diverse ant species are reported to inhabit highly disturbed, managed ecosystems, such as annual cropping systems [19]. Therefore, elucidating the influence of ant colonies on soil fertility and plant growth is of far-reaching significance. Thus, it is essential to ascertain whether PGPB are associated with ant nests and to find if they also affect plant growth via their effect on soil-borne pathogens.

Only scanty information is available regarding the influence of seed harvesting ant colonies on the microbial richness and these mainly pertain to the influence of the microbes on soil properties. Trichomyrmex scabriceps (Mayr 1865) is a seed harvester ant species widely distributed in many parts of India [23] but surprisingly, very little is known about its ecology. The nests of the seed-harvesting, T. scabriceps colonies are commonly found in hard, compact soil, such as that typically found on unpaved paths of agroecosystems, gardens and, roadsides (personal observations). Its nests are characterized by the presence of seed husk piles, a single pile being present at the nest entrance rim of a nest. Colonies of $T$. scabriceps have the potential to play a crucial role in linking the above-ground resources with the belowground biota, such as microbial communities.

In the present study, we have focused on the PGP microbiota associated with colonies of the Asian harvester ant, T. scabriceps (Mayr 1865), which is widely reported from a number of tropical and subtropical countries, including India and Sri Lanka [24]. Colonies of T. scabriceps commonly occur in arid and semiarid areas and the workers primarily forage on seeds. Our preliminary survey revealed the widespread occurrence of $T$. scabriceps colonies in 
our study area. Moreover, our field observations (since April, 2018) suggest that the main nests (each main nest being accompanied by 1-3 satellite nests) are fairly long-lived (at least > 3 years). The PGP activities of ant nest associated microorganisms were further analyzed by the seed biopriming (SBP) method. For the SBP study, seeds of chickpea (Cicer arietinum L.) were preferred since this is one of the largest produced pulse crops in semi-arid tropical countries, including India, where it comprises about $40 \%$ of the total pulse crop [25]. India being the largest producer of chickpea contributes around $65 \%$ of the world's total production. Although a high number of plant pathogens have been reported to attack the chickpea crop, Sclerotium rolfsii is a well-known soil-borne fungal pathogen of chickpea crop in tropical and subtropical areas of the world [26]. It attacks the crop at the early seedling stage (resulting in the collar rot disease) and causes 55-95\% mortality of chickpea seedlings under favorable environmental conditions [27]. The control of $S$. rolfsii in agriculture has been challenging, since the highly competitive saprophytic pathogen exhibits high survivability in dry climatic regions, occurs on a wide range of natural hosts and can persist in soil for prolonged periods even after several crop rotations [28]. Consequently, we examined the antagonistic (in-vitro) activities of isolated bacteria against $S$. rolfsii.

We hypothesize that soil fertility enhancement and the PGP effects of ant nest soil are due to the presence of associated PGPB. Due to the ecosystem engineering activities of ant colonies the ant nest soil with its high organic matter content provides suitable conditions for the growth of the PGPB, which could be directly involved in enhancing plant growth and possibly even in the reduction of soil-borne fungal pathogens such as, $S$. rolfsii. Therefore, in the present study, we addressed the following 4 inter-related questions: (1) Are the seed harvester ant colonies associated with PGPB? (2) Is there any difference between the abundance of PGPB in the debris pile and the nest chambers of $T$. scabriceps? (3) What is the direct impact of the PGPB isolates on plant growth? (4) Do these bacteria play any role in plant disease resistance?

\section{Methods}

\section{Experimental Design}

Soil Sample Collection. A total of 19 plots (area of each plot $=10 \times 10 \mathrm{~m}^{2}$ ) were randomly selected in the botanical garden (covering an area of $\sim 2$ hectares) of Banaras Hindu University (BHU), Varanasi, U.P., India $\left(25 \otimes 18^{\prime} \mathrm{N}, 83 \rrbracket 03^{\prime} \mathrm{E}\right)$. The soil samples were collected (during August 2018$)$, from the nest chambers and debris piles (located at the nest entrance rim) of $T$. scabriceps nests $(n=43)$ located in the field plots. The control garden soil samples were collected (from a depth of $10-20 \mathrm{~cm}$ ) from areas located at a distance of $\geq 5 \mathrm{~m}$ from ant nests and vegetation. Ant nest soil sample collection was done only from those nests which were located at a distance of $\geq 2 \mathrm{~m}$ from the nearest vegetated area.

\section{Isolation of PGP Bacteria}

The collected soil samples were brought to the laboratory and placed into three groups: group 1 (control) contained garden soil, group 2 (experimental), which comprised soil collected (as per the method used by Shukla et al. [19]) from the external refuse piles of the seed harvester ant nests, and group 3 (experimental), from the ant nest chambers (from a depth $\sim 9-20 \mathrm{~cm}$ ). Each soil sample was serially diluted up to $10^{-8}$ dilution to obtain isolated colonies. Next, $0.1 \mathrm{ml}$ of each serially diluted sample $\left(10^{-1}-10^{-8}\right)$ was transferred to the respectively labeled Petri plates containing the nutrient broth (for bacterial culture) and incubated at $28 \otimes \mathrm{C}$ for $24-48 \mathrm{~h}$. The serial dilution was carried out in triplicate, on agar plates, where bacteria were isolated based on the colonial morphology (including size, shape, and other extracellular characteristics) of each. Next, each of these was isolated as a pure culture and stored on Nutrient Agar (NA) slants at $4 \llbracket \mathrm{C}$.

\section{Biochemical PGP Assay}

For assessment of the plant growth-promotion abilities of the isolated bacteria, in-vitro phosphate solubilization, IAA production and siderophore production abilities were examined. Phosphate solubilization ability, estimated as per the method of Mehta and Nautiyal [29] involved inoculation of strains in National Botanical Research Institute's phosphate growth medium (NBRIP) [30] for $48 \mathrm{~h}$ at $28 \otimes \mathrm{C}$ and $120 \mathrm{rpm}$. The reduction of the molybdophosphoric acid to stannous chloride, was recorded at $660 \mathrm{~nm}$. IAA was estimated by using the method of Bric et al. [31]. The isolates were inoculated in Nutrient Broth (NB) containing tryptophan ( $5 \mathrm{mM})$, and then incubated for $48 \mathrm{~h}(28 \otimes \mathrm{C}, 120 \mathrm{rpm})$. The NB cultures were further subjected to centrifugation $(10,000 \mathrm{rpm}$ for $15 \mathrm{~min})$ and the supernatant was collected. One $\mathrm{ml}$ volume of the supernatant was mixed with $2 \mathrm{ml} \mathrm{Salkowski} \mathrm{reagent} \mathrm{(1} \mathrm{mL} \mathrm{of} 0.5 \mathrm{M}$ $\mathrm{FeCl} 3$ in $50 \mathrm{~mL}$ of $35 \% \mathrm{HClO}$; [32]) and kept in the dark for $30 \mathrm{~min}$. The chemical reaction resulting in a color change from yellow to pink/red showed a positive result for IAA production. The optical density (OD) was recorded at $535 \mathrm{~nm}$ by using a Thermo Scientific UV1 spectrophotometer. The siderophore production ability of isolates was assessed (both qualitatively and quantitatively) by the method of Bano and Musarrat [33].

\section{Assessment of the biocontrol potential of the isolated bacteria}

To investigate whether the bacterial isolates play any role in making the plant disease resistant, experiments were next conducted to find if they show any antagonistic activities against plant pathogens such as $S$. rolfsii.

Hence, further screening of the potential PGPB was done based on their effective antagonism against a well-documented [34], soil-borne plant pathogen, S. rolfsii (obtained from Mycology and Plant Pathology Dept., Institute of Agriculture, of BHU). Antagonistic activities of the isolated bacteria against $S$. rolfsii were evaluated in-vitro by using the dual-culture plate assay. In each case, a loopful of bacterial isolate was streaked, $2 \mathrm{~cm}$ away from the edge of each plate $(\mathrm{n}=3)$ containing NA. The pathogen was introduced on the plate by placing a plug (containing mycelia from the pure culture plates), $2 \mathrm{~cm}$ away from the other edge of the plate, on the side opposite to that inoculated by the isolated bacteria, maintaining a minimum distance of $5 \mathrm{~cm}$ between the two types of microbes. The plates were incubated at $27 \pm 2 \nabla \mathrm{C}$ and observed on the seventh day post-incubation where the percent inhibition of 
pathogen was measured in terms of the distance (growth) traveled (in $\mathrm{mm}$ ) by the pathogen and the bacterial colony towards each other on the same NA plate [35]. The experiment was set up in triplicate where the percent inhibition of the pathogen was calculated by using the following formula:

$I=(C \otimes T) \times 100 / C$

Where; $\mathrm{I}=$ percent $(\%)$ inhibition in mycelia growth; $\mathrm{C}=$ growth of pathogen in control plates (in $\mathrm{mm}$ ); $\mathrm{T}$ = growth of the pathogen in dual culture plates (in $\mathrm{mm})$.

Experimental setup

\section{Inoculum preparation for seed biopriming}

Pure culture of each bacterial isolate was inoculated in NB medium and placed in a shaker for $\sim 24-48 \mathrm{~h}$ (to attain the stationary phase). Later the

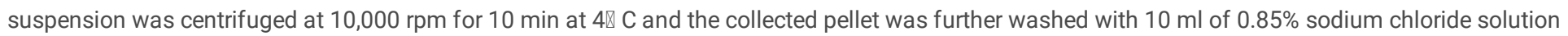
to remove the residual NB. Finally, the pellets were suspended in $25 \mathrm{ml}$ of $1 \%$ carboxymethyl cellulose (CMC) sodium salt suspension and vortexed vigorously to acquire a homogenous cell density of about $4 \times 10^{8} \mathrm{cfu} / \mathrm{ml}$ [36].

\section{Seed biopriming with prepared bacterial suspension}

Chickpea seeds were surface sterilized with $1 \%$ sodium hypochlorite ( $\mathrm{NaOCl}$ ) solution for $\sim 60 \mathrm{~s}$, and then rinsed with sterilized distilled water (SDW) thrice, followed by brief drying under laminar flow, on pre-sterilized blotting paper. For seed biopriming experiments, 20 chickpea seeds (for each isolate) were placed on freshly sterilized blotting paper placed in a sterilized Petri plate and the prepared bacterial suspension (100 $\mu l)$ was poured on the cluster of 20 seeds. The excess amount of suspension was drained out. Only CMC treated seeds were treated as the control. These plates with seeds were incubated at $28 \pm 2^{\circ} \mathrm{C}$, with $98 \%$ relative humidity for $24 \mathrm{~h}$.

\section{In-vitro plant growth-promotion assessment}

The growth-promoting ability of the bacterial isolates was assessed on chickpea seedlings by measuring its growth augmentation effect. The bioprimed seeds were placed in plastic pots, each containing a sterile sand-soil mixture. Each pot (treatment) contained 5 seedlings (single bacterial suspension) from a sterilized Petri plate. Also, each pot (treatment) had 5 replicates using a completely randomized design [37]. The pots were kept in the greenhouse chamber for 25 days at $28 \pm 2 \varangle \mathrm{C}$ and relative humidity $(\mathrm{RH})$ of $76 \%$. The control set contained only water-soaked seedlings. The isolate treated seeds expressing higher plant growth under gnotobiotic conditions were selected for phenylalanine ammonia-lyase (PAL), and peroxidase $(\mathrm{PO} X)$ assessment.

\section{Assessment of disease resistance in bioprimed seeds}

The pathogen was multiplied by the method of Sarma et al. [38] and the resulting colonized culture was inoculated at the collar region of bioprimed chickpea plants. From each treatment $(n=5)$ the nodal leaves from the bottom of the plant were collected after $24 \mathrm{~h}, 48 \mathrm{~h}$, and $96 \mathrm{~h}$ without causing any damage to the plant. The collected leaves were washed, dried, and stored in a deep freezer $\left(-80^{\circ} \mathrm{C}\right)$ for further use.

To assess phenylalanine ammonia-lyase (PAL) activity, the leaves of chickpea plants $(0.1 \mathrm{~g})$ of control and experimental plants, were homogenized in 2 $\mathrm{ml}$ sodium borate buffer $(0.1 \mathrm{M} ; \mathrm{pH} 7.0)$ containing $1.4 \mathrm{mM}$ mercaptoethanol. The resulting solution was centrifuged for $15 \mathrm{~min}$ at $16,000\left(4^{\circ} \mathrm{C}\right)$. The reaction mixture containing $200 \mu \mathrm{l}$ enzyme extract, $206 \mu \mathrm{l}$ phosphate buffer $(0.2 \mathrm{M}, \mathrm{pH} 8.7), 1.3 \mathrm{ml}$ distilled water and $1 \mathrm{ml} \mathrm{L}-\mathrm{phenylalanine}(0.1 \mathrm{M}$, pH 8.7) was incubated for 30 minutes at $32^{\circ} \mathrm{C}$. The ongoing reaction was terminated by adding $500 \mu \mathrm{l}$ trans-cinnamic acid ( $\left.1 \mathrm{M}\right)$ and the absorbance was recorded at $290 \mathrm{~nm}$ where PAL activity was expressed as $\mu \mathrm{M} \mathrm{TCA} \mathrm{g}^{-1}$ fresh weight (FW). To assess antioxidant activity, peroxidase (POx) activity was measured. Leaf sample $(0.1 \mathrm{~g})$ was homogenized in $5.0 \mathrm{ml}$ phosphate buffer $\left(0.1 \mathrm{M} ; \mathrm{pH} 7.0\right.$, ice cold), and further centrifuged at $16,000 \mathrm{rpm}\left(4^{\circ} \mathrm{C}\right.$ for 15 min). $50 \mu$ of enzyme extract (supernatant) was added to the reaction mixture containing $1.5 \mathrm{ml}$ of pyrogallol $(0.05 \mathrm{M})$ and $500 \mu \mathrm{l}$ of $1 \% \mathrm{H} 2 \mathrm{O} 2$. The reaction mixture without enzyme extract served as the control. The absorbance was recorded at $420 \mathrm{~nm}$ at intervals of 30 sec for 3 minutes until a constant change in absorbance value was attained. PO activity was expressed as $\mathrm{U} \mathrm{min}^{-1} \mathrm{~g}^{-1} \mathrm{FW}$ [39].

\section{Genomic DNA isolation}

Genomic DNA of the principal bacterial isolates was obtained by the method of Wilson [56] with a slight modification. The isolates were subjected to centrifugation and the culture pellets formed by the bacterial culture were subjected to lysozyme ( $0.5 \mathrm{mg} \mathrm{ml}-1)$, SDS ( $2.3 \%)$ and proteinase $\mathrm{K}(0.2 \mathrm{mg} \mathrm{ml}$ 1) treatments followed by heating at $55^{\circ} \mathrm{C}$ for $2-3 \mathrm{~h}$. The suspension was again centrifuged. Genomic DNA from the supernatant was extracted using phenol-chloroform-isopropanol and precipitated using ethanol. For taxonomic identification, the genomic DNA (16S rDNA) of the isolated bacteria were submitted to Eze Diagon Healthcare Pvt, Ltd, Coimbatore, Tamil Nadu, India. The nucleotide sequences (PCR amplified) thus obtained were next submitted to NCBI GenBank to get the Accession Numbers. Further, a phylogenetic tree with isolates was constructed using MEGA 6 software to substantiate the classification.

\section{Statistical Analyses}

Data was statistically analyzed by ANOVA, and the treatment means were separated by Duncan's multiple range test (DMRT) at P < 0.05 using SPSS version 19.0 (SPSS Inc., USA).

Results 
The control soil sample contained a total of 18 bacterial isolates, whereas the ant nest associated soil contained 57 and 27 bacterial isolates respectively obtained from the nest debris piles and nest chambers.

Table 1

Biochemical and physiological characterization of bacterial isolates from control soil (from 10-20cm depth, 5-10m away from ant nest

\begin{tabular}{|c|c|c|c|c|}
\hline Bacterial isolate & $\begin{array}{l}\text { Phosphate solubilization } \\
\left(\mu \mathrm{g} \mathrm{ml}^{-1}\right)\end{array}$ & $\begin{array}{l}\text { IAA production } \\
\left(\mu \mathrm{g} \mathrm{ml}^{-1}\right)\end{array}$ & $\begin{array}{l}\text { Siderophore } \\
\text { production } \\
(\%)\end{array}$ & $\begin{array}{l}\text { Biocontrol potential } \\
(\%)\end{array}$ \\
\hline CB01 & $33.67 \pm 0.251^{d}$ & $27.86 \pm 0.005^{d}$ & - & - \\
\hline СB02 & $29.43 \pm 0.252^{\mathrm{e}}$ & $11.36 \pm 0.065^{\mathrm{m}}$ & $14.63 \pm 0.374^{f}$ & - \\
\hline CB03 & $35.97 \pm 1.053^{c}$ & $23.66 \pm 0.005^{\mathrm{e}}$ & $18.48 \pm 0.418^{d}$ & $36.87 \pm 0.821^{d}$ \\
\hline CBO4 & $38.63 \pm 1.263^{a}$ & $36.37 \pm 0.009^{a}$ & $31.08 \pm 0.535^{a}$ & $69.67 \pm 1.062^{\mathrm{a}}$ \\
\hline CB05 & $39.03 \pm 1.103^{a}$ & $31.45 \pm 0.106^{c}$ & $27.13 \pm 0.603^{b}$ & $61.34 \pm 1.528^{b}$ \\
\hline СB06 & $22.73 \pm 0.303^{h}$ & $13.71 \pm 0.068^{k}$ & - & - \\
\hline СВ07 & $28.63 \pm 0.603^{f}$ & $12.26 \pm 0.009^{\mid}$ & $11.40 \pm 0.197^{g}$ & \\
\hline СВ08 & $31.53 \pm 0.745^{\mathrm{jk}}$ & $17.02 \pm 0.001^{i}$ & - & - \\
\hline СB09 & $29.87 \pm 0.702^{\mathrm{ef}}$ & $19.02 \pm 0.006^{g}$ & $16.63 \pm 0.354^{e}$ & $12.67 \pm 2.082^{f}$ \\
\hline \multicolumn{5}{|c|}{+ Values are the means of three replicates \pm SE mean where - indicates no growth/no } \\
\hline \multicolumn{5}{|l|}{ activity. } \\
\hline
\end{tabular}

\section{Biochemical and physiological screening}

Microbial isolates demonstrating PGP characteristics were distinguished based on the preliminary biochemical screening involving the 3 types of in vitro plant growth-promotion assays: phosphate solubilization, IAA and siderophore production.

The nest debris soil harbored $63 \%$ (23 bacterial isolates) of isolates, with phosphate solubilization ability (ranging from $12 \mu \mathrm{g} / \mathrm{ml}$ to $108 \mu \mathrm{g} / \mathrm{ml}$ ), whereas only $57 \%$ ( 21 bacterial isolates) of isolates were able to produce IAA, ranging from $10 \mu \mathrm{g} / \mathrm{ml}$ to $57 \mu \mathrm{g} / \mathrm{ml}$. Further 10 isolates among them had the ability to produce siderophore (Table 2, SF 1). The highest (76\%) phosphate solubilizing ability was demonstrated by the bacterial isolate MDB15 and the trend in the decreasing order was: MDB15 (76\%) > MDB07 (63\%) > MDB19 (57\%) > MDB12 (54\%) > MDB09 (38\%). These isolates also expressed biocontrol potential against the plant pathogen, $S$. rolfsii. About $17 \%$ of total isolates showed positive results for all three characteristics (Table 3 ). 
Table 2

Biochemical and physiological characterization of bacterial isolates: MDB (01-23) from debris soil of Trichomyrmex scabriceps ant colonies

\begin{tabular}{|c|c|c|c|c|}
\hline Bacterial isolate & $\begin{array}{l}\text { Phosphate solubilization } \\
\left(\mu \mathrm{g} \mathrm{ml}^{-1}\right)\end{array}$ & $\begin{array}{l}\text { IAA production } \\
\left(\mu \mathrm{g} \mathrm{ml}^{-1}\right)\end{array}$ & $\begin{array}{l}\text { Siderophore } \\
\text { production } \\
(\%)\end{array}$ & $\begin{array}{l}\text { Biocontrol potential } \\
\text { (\%) }\end{array}$ \\
\hline MDB01 & $14.22 \pm 0.555^{c}$ & $10.46 \pm 0.025^{a}$ & - & - \\
\hline MDB02 & $30.43 \pm 0.252^{\mathrm{jk}}$ & $10.26 \pm 0.055^{a}$ & - & - \\
\hline MDB03 & $30.14 \pm 1.749^{j}$ & $16.18 \pm 0.010^{e}$ & $8.10 \pm 0.448^{b}$ & - \\
\hline MDB04 & $15.90 \pm 0.100^{d}$ & $17.50 \pm 0.080^{f g}$ & $10.08 \pm 0.254^{c}$ & - \\
\hline MDB05 & $23.03 \pm 0.503^{g}$ & $15.45 \pm 0.106^{d}$ & $7.13 \pm 0.603^{a}$ & - \\
\hline MDB06 & $12.73 \pm 0.503^{b}$ & $13.51 \pm 0.068^{c}$ & $11.60 \pm 0.447^{d}$ & - \\
\hline MDB07 & $108.63 \pm 0.603^{p}$ & $42.26 \pm 0.007^{\mathrm{m}}$ & $51.40 \pm 0.197^{k}$ & $89 \pm 5^{d}$ \\
\hline MDB08 & $31.53 \pm 0.945^{j \mathrm{k}}$ & $19.02 \pm 0.001^{f}$ & - & - \\
\hline MDB09 & $31.87 \pm 0.702^{k}$ & $29.02 \pm 0.006^{j}$ & $16.63 \pm 0.354^{g}$ & $12.67 \pm 2.082^{\mathrm{a}}$ \\
\hline MDB10 & $66.53 \pm 1.002^{n}$ & $21.66 \pm 0.013^{g}$ & $13 \pm 0.471^{\mathrm{e}}$ & - \\
\hline MDB11 & $19.20 \pm 0.300^{f}$ & $14.11 \pm 0.005^{c}$ & $7.84 \pm 0.059^{b}$ & - \\
\hline MDB12 & $76.27 \pm 0.551^{\mathrm{m}}$ & $47.42 \pm 0.006^{\mid}$ & $32.58 \pm 0.472^{i}$ & $44.67 \pm 3.055^{b}$ \\
\hline MDB13 & $22.95 \pm 0.852^{\mathrm{g}}$ & $19.77 \pm 0.014^{\mathrm{h}}$ & - & - \\
\hline MDB14 & $26.40 \pm 0.536^{i}$ & $17.60 \pm 0.006^{\mathrm{fg}}$ & - & - \\
\hline MDB15 & $41.83 \pm 1.795^{\circ}$ & $37.37 \pm 0.009^{n}$ & $47.08 \pm 0.535^{j}$ & $65.68 \pm 2.517^{c}$ \\
\hline MDB16 & $18.11 \pm 0.800^{\text {ef }}$ & $11.33 \pm 0.006^{\mathrm{b}}$ & - & - \\
\hline MDB17 & $13.31 \pm 0.302^{\mathrm{a}}$ & $10.12 \pm 0.001^{\mathrm{a}}$ & - & - \\
\hline MDB18 & $13.18 \pm 0.426^{a}$ & $11.19 \pm 0.001^{\mathrm{b}}$ & - & - \\
\hline MDB19 & $36.87 \pm 0.351^{1}$ & $21.86 \pm 0.005^{\mathrm{k}}$ & $18.48 \pm 0.428^{h}$ & $12.33 \pm 1.528^{a}$ \\
\hline MDB20 & $24.71 \pm 1.589^{h}$ & $57.06 \pm 0.001^{i}$ & $14.60 \pm 0.365^{f}$ & - \\
\hline MDB21 & $11.76 \pm 0.550^{b}$ & - & - & - \\
\hline MDB22 & $17.12 \pm 0.694 d^{e}$ & $12.85 \pm 0.756^{g}$ & - & - \\
\hline MDB23 & $18.107 \pm 0.703^{\text {ef }}$ & - & - & - \\
\hline \multicolumn{5}{|c|}{+ Values are the means of three replicates \pm SE mean where - indicates no growth/no } \\
\hline activity. & & & & \\
\hline
\end{tabular}

However, $78 \%$ of the total isolates present in the ant nest chamber soil demonstrated phosphate solubilization ability, ranging from $22 \mu \mathrm{g} / \mathrm{ml}$ to 293 $\mu \mathrm{g} / \mathrm{ml}$, and $52 \%$ of total isolates efficiently produced IAA (21 bacterial isolates), ranging from $12 \mu \mathrm{g} / \mathrm{ml}$ to $53 \mu \mathrm{g} / \mathrm{ml}$. while 6 isolates showed efficient siderophore producing ability. Among these bacterial isolates: MNB05 (33\%), MNB06 (78\%), and MNB08 (69\%) also indicated biocontrol potential (Table 3 , SF 2). In contrast to the ant nest soil, the control soil contained fewer bacteria (45\% phosphate solubilizing, $27 \%$ IAA producing, $11 \%$ siderophore producing and with biocontrol potential) with PGP activity (Table 1).

\section{Table 3}

Biochemical and physiological characterization of bacterial isolates: MNB (01-17) from nest chamber soil of Trichomyrmex scabriceps ant colonies 


\begin{tabular}{|c|c|c|c|c|}
\hline $\begin{array}{l}\text { Bacterial } \\
\text { isolate }\end{array}$ & $\begin{array}{l}\text { Phosphate solubilization } \\
\left(\mu \mathrm{g} \mathrm{ml}^{-1}\right)\end{array}$ & $\begin{array}{l}\text { IAA production } \\
\left(\mu \mathrm{g} \mathrm{ml}^{-1}\right)\end{array}$ & $\begin{array}{l}\text { Siderophore } \\
\text { production } \\
(\%)\end{array}$ & $\begin{array}{l}\text { Biocontrol potential } \\
(\%)\end{array}$ \\
\hline MNB01 & $29.45 \pm 0.12^{c}$ & - & - & - \\
\hline MNB02 & $29.45 \pm 0.12^{\mathrm{c}}$ & - & & - \\
\hline MNB03 & $28.58 \pm 0.25^{d}$ & $27.55 \pm 0.769^{e}$ & $19.45 \pm 0.239^{d}$ & - \\
\hline MNB04 & $182.58 \pm 0.41^{k}$ & $31.15 \pm 0.154^{f}$ & $23.20 \pm 0.307^{\mathrm{e} \pm}$ & - \\
\hline MNB05 & $208.46 \pm 0.24^{\mathrm{m}}$ & $43.47 \pm 0.924^{h}$ & $31.11 \pm 0.864^{f}$ & $68 \pm 2.16^{b}$ \\
\hline MNB06 & $271.20 \pm 0.36^{p}$ & $50.31 \pm 0.153^{k}$ & $67.43 \pm 0.347^{g}$ & $87 \pm 2.49^{c}$ \\
\hline MNB07 & $68.312 \pm 0.52^{f}$ & $12.02 \pm 0.077^{a}$ & - & - \\
\hline MNB08 & $292.69 \pm 0.14^{q}$ & $53.29 \pm 0.153^{j}$ & $71.33 \pm 0.257^{i}$ & $96 \pm 1.63^{\mathrm{e}}$ \\
\hline MNB09 & $22.49 \pm 0.251^{\mathrm{e}}$ & - & $18.15 \pm 0.141^{c}$ & \\
\hline MNB10 & $119.13 \pm 0.24^{\circ}$ & - & $10.86 \pm 0.663^{a}$ & $11 \pm 0.82^{a}$ \\
\hline MNB11 & $63.55 \pm 0.14^{1}$ & $39.73 \pm 0.133^{g}$ & $16.35 \pm 0.12^{b}$ & - \\
\hline MNB12 & $97.33 \pm 0.74^{i}$ & $6.98 \pm 0.077^{c}$ & - & - \\
\hline MNB13 & $31.85 \pm 0.27^{a}$ & - & - & - \\
\hline MNB14 & $104.62 \pm 1.29^{j}$ & $29.95 \pm 0.671^{f}$ & - & - \\
\hline MNB15 & $23.11 \pm 0.74^{b}$ & - & - & - \\
\hline MNB16 & $74.66 \pm 0.27^{g}$ & $15.91 \pm 0.154^{c}$ & - & - \\
\hline MNB17 & $76.86 \pm 0.14^{h}$ & $14.27 \pm 0.133^{b}$ & - & - \\
\hline
\end{tabular}

+ Values are the means of three replicates \pm SE mean where - indicates no growth/no activity.

$\ddagger$ Values followed by different letters within a column are significantly different according to Duncan's multiple range test $(P<0.05)$.

\section{Effects of selected isolates on seed germination and growth of chickpea}

After preliminary screening, a total of 6 isolates; MDB07, MDB09, MDB12, MDB15, MDB19, and MDB20 from nest debris piles and a total of 6 isolates; MNB03, MNB04, MNB05, MNB06, MNB08, and MNB10 from ant nest chambers were selected for seed biopriming, to assess their biofertilizer potential. All the isolates showed positive results for at least two of the biochemical assays (Table 2\&3). The selected bacterial isolates when applied to chickpea seeds significantly enhanced seed germination, shoot length, root length and plant biomass (shoot fresh weight, root fresh weight, shoot dry weight, root dry weight) as compared to the negative control, in each case. Seed germination percentage increased up to $80 \%$ with debris pile soil isolates, and up to $89 \%$ in the case of nest chamber soil isolates. The shoot length was enhanced from $6.22-14.39 \%$ by the debris soil isolates and by $5.77-16.19 \%$ by the nest chamber soil isolates. The isolated bacteria effectively intensified root length up to $18.72 \%$ in the case of debris soil isolates and $14.45 \%$ by the nest soil isolates. In addition, bacterial isolates augmented total fresh weight (debris isolates: $28.65 \%-59.42 \%$, nest isolates: $28.65 \%-59.42 \%$ ) and total dry weight (debris soil isolates: $28.65 \%-59.42 \%$, nest chamber soil isolates: $28.65 \%-59.42 \%$ ) of chickpea seedlings (Table $4 \& 5$ ). Among 13 bacterial inoculants, treatment with MDB15, MDB12 from debris piles and MNB06, and MNB08 from nest chamber showed the highest PGP abilities for all growth parameters (SF 3). Hence, they were further analyzed for anti-oxidative enzyme activities. 
Table 4

Effect of selected bacterial isolates: MDB $(07,09,12,15,19$ and 20), from nest debris soil of Trichomyrmex scabriceps ant colonies on plant growth promotion: Seed germination (SG), Shoot length $(\mathrm{SL})$, Root length (RL), Shoot fresh weight (SFW), Root fresh Weight (RFW), Total fresh weight (TFW) and Total dry weight (TDW).

\begin{tabular}{|c|c|c|c|c|c|c|c|c|c|}
\hline \multicolumn{10}{|c|}{ Treatment Plant growth characteristics } \\
\hline & SG & SL & $\mathrm{RL}$ & SFW & SDW & RFW & RDW & TFW & TDW \\
\hline & $(\%)$ & $(\mathrm{cm})$ & $(\mathrm{cm})$ & (gm) & (gm) & (gm) & $(\mathrm{gm})$ & (gm) & $(\mathrm{gm})$ \\
\hline \multirow[t]{2}{*}{ Control } & $40 \pm$ & $6.29 \pm$ & $7.574 \pm$ & $0.147 \pm$ & $0.019 \pm$ & $0.127 \pm$ & $0.015 \pm$ & $0.273 \pm$ & $0.034 \pm$ \\
\hline & $1.58^{\mathrm{a}}$ & $0.022^{a}$ & $0.021^{a}$ & $0.022^{a}$ & $0.006^{a}$ & $0.022^{\mathrm{a}}$ & $0.004^{a}$ & $0.036^{\mathrm{a}}$ & $0.006^{a}$ \\
\hline \multirow[t]{2}{*}{ MDB07 } & $80 \pm$ & $12.77 \pm$ & $14.66 \pm$ & $0.331 \pm$ & $0.057 \pm$ & $0.262 \pm$ & $0.033 \pm$ & $0.592 \pm$ & $0.089 \pm$ \\
\hline & $1.58^{\mathrm{cd}}$ & $0.033^{f}$ & $0.115^{f}$ & $0.013^{d}$ & $0.010^{c}$ & $0.024^{d}$ & $0.005^{b c}$ & $0.027^{d}$ & $0.009^{d}$ \\
\hline \multirow[t]{2}{*}{ MDB09 } & $58 \pm$ & $10.16 \pm$ & $9.706 \pm$ & $0.273 \pm$ & $0.044 \pm$ & $0.177 \pm$ & $0.030 \pm$ & $0.450 \pm$ & $0.074 \pm$ \\
\hline & $1.48^{\mathrm{b}}$ & $0.033^{c}$ & $0.017^{c}$ & $0.024^{c}$ & $0.013^{b c}$ & $0.014^{b}$ & $0.004^{b}$ & $0.045^{c}$ & $0.015^{\mathrm{cd}}$ \\
\hline \multirow[t]{2}{*}{ MDB12 } & $74 \pm$ & $12.33 \pm$ & $16.35 \pm$ & $0.294 \pm$ & $0.051 \pm$ & $0.275 \pm$ & $0.034 \pm$ & $0.569 \pm$ & $0.085 \pm$ \\
\hline & $3.6^{\mathrm{ef}}$ & $0.022^{c}$ & $0.271^{e}$ & $0.015^{c}$ & $0.018^{c}$ & $0.030^{d}$ & $0.003^{b c}$ & $0.023^{d}$ & $0.016^{d}$ \\
\hline \multirow[t]{2}{*}{ MDB15 } & $86 \pm$ & $14.39 \pm$ & $18.72 \pm$ & $0.378 \pm$ & $0.078 \pm$ & $0.327 \pm$ & $0.037 \pm$ & $0.705 \pm$ & $0.115 \pm$ \\
\hline & $1.14^{f}$ & $0.043^{g}$ & $0.018^{\mathrm{g}}$ & $0.021^{\mathrm{e}}$ & $0.014^{d}$ & $0.012^{\mathrm{e}}$ & $0.002^{c}$ & $0.028^{e}$ & $0.015^{\mathrm{e}}$ \\
\hline \multirow[t]{2}{*}{ MDB19 } & $56 \pm$ & $10.55 \pm$ & $10.28 \pm$ & $0.239 \pm$ & $0.031 \pm$ & $0.222 \pm$ & $0.031 \pm$ & $0.462 \pm$ & $0.062 \pm$ \\
\hline & $1.52^{\mathrm{b}}$ & $0.033^{d}$ & $0.066^{d}$ & $0.019^{b}$ & $0.011^{a b}$ & $0.026^{c}$ & $0.003^{b}$ & $0.022^{c}$ & $0.010^{\mathrm{bc}}$ \\
\hline \multirow[t]{2}{*}{ MDB20 } & $64 \pm$ & $8.35 \pm$ & $8.810 \pm$ & $0.224 \pm$ & $0.033 \pm$ & $0.151 \pm$ & $0.018 \pm$ & $0.374 \pm$ & $0.051 \pm$ \\
\hline & $1.14^{\mathrm{bc}}$ & $0.031^{b}$ & $0.111^{b}$ & $0.015^{\mathrm{b}}$ & $0.012^{\mathrm{ab}}$ & $0.020^{a b}$ & $0.004^{a}$ & $0.044^{b}$ & $0.008^{b}$ \\
\hline \multicolumn{10}{|c|}{${ }^{\dagger}$ Values are the means of 5 replicates with each isolate \pm SE mean. } \\
\hline \multicolumn{10}{|c|}{ ‡ Values followed by different letters within a column are significantly different according to } \\
\hline \multicolumn{10}{|c|}{ Duncan's multiple range test $(P<0.05)$. } \\
\hline
\end{tabular}


Table 5

Effect of selected bacterial isolates: $\operatorname{MNB}(03,04,05,06,08$ and 10), from the nest chamber soil of Trichomyrmex scabriceps ant colonies on plant growth promotion. Seed germination (SG), Shoot length (SL), Root length (RL), Shoot fresh weight (SFW), Root fresh Weight (RFW), Total fresh weight (TFW) and Total dry weight (TDW).

\begin{tabular}{|c|c|c|c|c|c|c|c|c|c|}
\hline \multicolumn{10}{|c|}{ Treatment Plant growth characteristics } \\
\hline & SG & SL & $\mathrm{RL}$ & SFW & SDW & RFW & RDW & TFW & TDW \\
\hline & $(\%)$ & $(\mathrm{cm})$ & $(\mathrm{cm})$ & $(\mathrm{gm})$ & $(\mathrm{gm})$ & (gm) & (gm) & $(\mathrm{gm})$ & (gm) \\
\hline \multirow[t]{2}{*}{ Control } & $41.7 \pm$ & $5.77 \pm$ & $5.23 \pm$ & $0.28 \pm$ & $0.042 \pm$ & $0.218 \pm$ & $0.022 \pm$ & \multirow{2}{*}{$0.496 \pm 0.034^{\mathrm{a}}$} & $0.064 \pm$ \\
\hline & $1.528^{\mathrm{a}}$ & $1.294^{\mathrm{a}}$ & $1.033^{\mathrm{a}}$ & $0.022^{\mathrm{a}}$ & $0.009^{a}$ & $0.025^{\mathrm{a}}$ & $0.002^{\mathrm{a}}$ & & $0.007^{a}$ \\
\hline MNB & $62.0 \pm$ & $9.91 \pm$ & $7.51 \pm$ & $0.38 \pm$ & $0.052 \pm$ & \multirow{2}{*}{$0.275 \pm 0.014^{\mathrm{b}}$} & $0.034 \pm$ & $0.660 \pm$ & \multirow[t]{2}{*}{$0.086 \pm 0.010^{b}$} \\
\hline 03 & $1.732^{d}$ & $1.208^{\mathrm{b}}$ & $1.208^{b c}$ & $0.024^{b c}$ & $0.009^{a}$ & & $0.005^{b}$ & $0.028^{c}$ & \\
\hline MNB & $55.3 \pm$ & $8.75 \pm$ & $8.77 \pm$ & $0.41 \pm$ & $0.065 \pm$ & $0.321 \pm$ & \multirow{2}{*}{$0.038 \pm 0.005^{\mathrm{bcd}}$} & $0.727 \pm$ & $0.104 \pm$ \\
\hline 04 & $1.155^{\mathrm{C}}$ & $1.134^{c}$ & $1.136^{\mathrm{cd}}$ & $0.021^{c d}$ & $0.009^{b}$ & $0.026^{c}$ & & $0.038^{d}$ & $0.010^{c}$ \\
\hline MNB & $80.7 \pm$ & $11.91 \pm 1.136^{\mathrm{d}}$ & $9.11 \pm$ & $0.44 \pm$ & $0.093 \pm$ & \multirow[t]{2}{*}{$0.368 \pm 0.021^{d}$} & \multirow[t]{2}{*}{$0.041 \pm 0.006^{c}$} & $0.805 \pm$ & \multirow[t]{2}{*}{$0.134 \pm 0.006^{d}$} \\
\hline 05 & $1.155^{\mathrm{e}}$ & & $1.108^{d}$ & $0.059^{d}$ & $0.008^{c}$ & & & $0.063^{\mathrm{e}}$ & \\
\hline MNB & $86.0 \pm$ & $16.19 \pm 0.853^{f}$ & $12.79 \pm 1.291^{f}$ & $0.69 \pm$ & $0.122 \pm$ & \multirow[t]{2}{*}{$0.469 \pm 0.025^{\mathrm{e}}$} & $0.060 \pm$ & $1.158 \pm$ & \multirow[t]{2}{*}{$0.182 \pm 0.009^{e}$} \\
\hline 06 & \multicolumn{3}{|l|}{$1.000^{f}$} & $0.036^{f}$ & $0.009^{d}$ & & $0.007^{d}$ & $0.020^{\mathrm{g}}$ & \\
\hline MNB & $88.7 \pm$ & $14.02 \pm 0.762^{\mathrm{g}}$ & $10.75 \pm$ & $0.49 \pm$ & $0.100 \pm 0.006^{\mathrm{e}}$ & $0.390 \pm$ & $0.044 \pm 0.005^{c}$ & $0.882 \pm$ & $0.143 \pm 0.009^{d}$ \\
\hline 08 & \multicolumn{2}{|l|}{$0.577^{\mathrm{g}}$} & $1.025^{\mathrm{e}}$ & $0.049^{\mathrm{e}}$ & & \multicolumn{2}{|l|}{$0.016^{d}$} & \multicolumn{2}{|l|}{$0.035^{f}$} \\
\hline MNB & $44.3 \pm$ & $10.77 \pm$ & $6.35 \pm$ & $0.34 \pm$ & $0.045 \pm$ & \multirow[t]{2}{*}{$0.251 \pm 0.017^{b}$} & $0.025 \pm$ & \multirow[t]{2}{*}{$0.587 \pm 0.037^{b}$} & $0.071 \pm$ \\
\hline 10 & $1.528^{b}$ & $0.848^{\mathrm{e}}$ & $1.134^{\mathrm{ab}}$ & $0.031^{b}$ & $0.007^{a}$ & & $0.007^{a}$ & & $0.009^{a}$ \\
\hline \multicolumn{10}{|c|}{${ }^{\dagger}$ Values are the means of 5 replicates with each isolate \pm SE mean. } \\
\hline \multicolumn{10}{|c|}{ ‡ Values followed by different letters within a column are significantly different according to } \\
\hline \multicolumn{10}{|c|}{ Duncan's multiple range test $(P<0.05)$. } \\
\hline
\end{tabular}

\section{Assessment of PAL and POx activities}

Significantly higher PAL enzyme concentrations were recorded in the leaves of experimental seedlings as compared to those from control, the highest being in case of those treated by the isolate MNB08 (1430.18 U min -1 g-1 FW), the next in the decreasing order being treatments involving MNB06 (1262 U min -1 g-1 FW), MDB07 (1003 U min -1 g-1 FW) and MDB15 (1215 U min -1 g-1 FW) isolates (Fig. 1A). Also, the pattern of PO activity was found to be almost similar in treatments ranging from $6.45 \mathrm{U} \mu \mathrm{l}-1 \mathrm{~min}-1$ for MNB08 to $3.91 \mathrm{U} \mu \mathrm{l}-1 \mathrm{~min}-1$ for MNB15 (Fig. 1B). The highest activity of enzymes was observed at $72 \mathrm{~h}$ in all the treatments which gradually declined at $96 \mathrm{~h}$ (Fig. 1).

Finally, the foremost selected PGP bacterial isolates were identified at the molecular level with greater than 95\% sequence similarity. The control soil contained bacterial isolates belonging to Enterobacter sp. (СB01), Micrococcus sp. (CB03), Bacillus sp. (CB04), Serratia sp. (CB05), and Clostridium sp. (СВ09) while T. scabriceps refuse pile soil contained Bacillus amyloliquifaciens MDB07 (MT864742.1), Bacillus sp. MDB09 (MT864743.1), Azotobacter chrococcum MDB12 (MT864745.1), Bacillus subtilis MDB15(MT781408.1), Bacillus sp. MDB19 (MT864744.1) and Klebsiella pneumoniae MDB20 (MT781409.1) (Fig. 2). The nest chamber soil supported six PGP bacterial isolates which were identified as Comamonas zongliani MNB03 (MT782285.1), Comamonas sp. MNB04 (MT864740.1), Tsukamurella paurometabola MNB05 (MT864741.1), Bacillus tequilensis MNB06 (MT782282.1), Bacillus valezensis MNB08 (MT782283.1) and Psudoxanthomonas spadix MNB10 (MT782284.1) (Fig. 2).

\section{Discussion}

The results of the present study reveal that the nests of the seed harvester, T. scabriceps ant colonies harbor a high diversity of PGPB which can directly enhance soil fertility and indirectly augment the growth of plants present in its vicinity. The present study provides clear evidence in support of the important ecological role of seed harvester ant colonies in serving as nutrient-enhancing links between aboveground plant resources and the belowground microbial communities. The control soil contained a lower diversity of PGPB than the debris pile and nest chamber soil of ant colonies (Table 2). The refuse pile soil of $T$. scabriceps colonies supported a higher number of phosphate solubilizing, IAA and siderophore producing bacteria as compared to those recorded in the ant nest chamber soil (Table 3). Among the bacterial isolates obtained from the debris soil, $68 \%$ of isolates demonstrated PGP potential either by phosphate solubilization or by IAA production, whereas $82 \%$ of the bacteria isolated from the nest chamber soil 
exhibited the PGP potential. The siderophore producing bacteria were more abundant in the debris soil (Table 2). The enrichment of ant nest soil with certain bacterial taxa could be distinguished at the phylum level itself. For instance, the abundance of bacteria belonging to genus Firmicutes was evident in the refuse pile soil, while those belonging to Actinobacteria and Proteobacteria genera were prominent in the nest chamber soil. The experimental exposure of the chick pea plants to the pathogen S. rolfsii (by its inoculation in the potted soil) induced higher production of PAL and PO enzyme activities in the chick-pea plants (Fig. 1). The production of PAL and POx enzyme in the experimental increased progressively from 24 to 72 hours after pathogen inoculation. These results support earlier findings which show similar pattern of higher production of defensive chemical compounds such as lignin and phenol due to the effects of rhizobacteria on S. rolfsii challenged plants [40, 41]. The higher PO enzyme production may be related to the reduction in reactive oxygen species level that gets accumulated due to pathogen infection [42].

Our results also indicate that the abundance of Bacillus species in the nest pile soil could be contributing towards the nutrient richness of the refuse dumps reported in seed harvester ant nests [43]. Earlier studies reveal that bacterial species such as $B$. amyloliquifaciens and $B$. subtilis easily colonize plant roots [44,45], and exert activity against many root or soil pathogens by secreting various metabolites $[45,43,46]$. Azotobacter chrococcum, also known as a nutrient indicator, is known to maintain plant health by fixing nitrogen [47]. Many of the bacterial species found to be associated with $T$. scabriceps ant colonies, in the present study, are documented to be widely used for soil bioremediation and as biofertilizer at the commercial level [48]. As far as we are aware this is the first report of the association of many PGPB with the nest soil of the seed harvesting, T. scabriceps colonies. Also, this is the first report of the antagonistic effect of ant nest associated PGPB on the soil pathogen, S. rolfsii.

While Firmicutes, Bacillus, Azotobacter, and Comamonas were the dominant bacterial genera associated with the nest soil of $T$. scabriceps ant colonies, as found in the present study, species belonging to Ochrobactrum and Pantoea genera were reported in the nest soil of the sugar-loving Camponotus compressus colonies [3]. It is likely that the composition of ant nest associated microbial communities is strongly influenced by the nature of available substrates which in turn would be strongly influenced by the type of food collected and consequently the foraging ecology of the ant species.

We suggest that the predominance of Bacillus species can be useful for both the $T$ scabriceps colonies and the plant species. Since both $B$. velezensis and $B$. tequelensis reportedly exhibit biocontrol potential (Table 2 ) against seed pathogens $[49,50]$, it is highly likely that these bacteria help in the protection of seeds collected by seed harvester ant colonies. Earlier studies on fungus-growing, Trachymyrmex cf. zeteki ants have shown the symbiotic association of ants with actinomycetous bacteria which occur in the infrabuccal pocket of ants and produce antibiotics that inhibit the parasitic microfungus belonging to genus, Escovopsis [51]. Thus, the colonies of $T$. scabriceps ants may also have adaptedly maintained these soil bacteria to obtain protection against soil pathogens so as to safeguard the foraged seeds.

Our preliminary studies on $T$. scabriceps revealed that each main nest is associated with 2-4 satellite nests, each with 1-2 chambers functioning as granaries (pers. obs.). The diverse plant seeds present in these granaries are thus enriched with the beneficial bacteria. Further, these bacteria-protected seeds present in the satellite nests of $T$. scabriceps have the potential to be the future plants, particularly in the semi-arid areas, favoured by these species. Thus, colonies of seed harvesting ants concentrate organic matter and nutrients near their nests and can create biogeochemical hotspots in nutrient-poor areas. The other PGPB such as C. zongliani, Comamonas sp. [52], and P. spadix [53] are of significance from the perspective of soil bioremediation.

The plant-growth-promoting bacteria associated with ant nest soil provide phosphorus, along with other nutrients to the plants, while the antimicrobial metabolites from these bacteria can efficiently protect the plants from harmful microbes, such as the soil pathogen, $S$. rolfsii. Some of these bacteria (such as Azotobacter sp.) also possess the ability to fix atmospheric nitrogen. Besides solubilizing phosphorous, these ant nest associated bacteria contribute towards the release of phytohormones, and enzymes, all of which contribute towards plant growth and yield. In conclusion, our findings show that the colonies of seed harvester ant, $T$ scabriceps are associated with various species of PGPB. The nutrient- and microbe-rich refuse piles of $T$. scabriceps colonies are not only of crucial importance for initiating habitat heterogeneity but the ant colony generated "hot spots" have implication for enhancing plant productivity in that area. Because the beneficial bacterial community of seed harvester refuse piles has immense potential to improve the plant growth-favouring attributes of the soil, they can promote seed protection and plant growth in arid and semi-arid areas, where they commonly occur as well as in many managed ecosystems, such as agricultural fields.

\section{Conclusion}

In conclusion, our findings show that the colonies of seed harvester ant, $T$ scabriceps are associated with various species of PGPB. The nutrient- and microbe-rich refuse piles of $T$. scabriceps colonies are not only of crucial importance for initiating habitat heterogeneity but the ant colony generated "hot spots" have implication for enhancing plant productivity in that area. Because the beneficial bacterial community of seed harvester refuse piles has immense potential to improve the plant growth-favoring attributes of the soil, they can promote seed protection and plant growth in arid and semi-arid areas, where they commonly occur as well as in many managed ecosystems, such as agricultural fields.

\section{Declarations}

Ethics Approval Not applicable.

Competing interests-The authors declare that they have no conflict of interest. 
Author Contributions-Rastogi NK designed the study and added comments in the drafts. Kumari P collected the soil sample and analysed the data. Rajput RS assisted in microbe isolation, and data analysis related to gnotobiotic plant growth promotion. Singh HB helped with the microbe identification.

Funding-The first author is grateful to UGC-JRF for financial assistance. Infrastructural support from UGC(CAS) is gratefully acknowledged.

\section{References}

1. Shukla RK, Singh H, Rastogi N (2016) How effective are disturbance-tolerant, agroecosystem nesting ant species in improving soil fertility and crop yield? Appl Soil Ecol 108:156-164. https://doi.org/10.1016/j.apsoil.2016.08.013

2. Shukla RK, Rastogi N, Singh H (2018) Contribution of the nutrient-enriched ant nest debris soil to growth and yield of Kalmegh (Andrographis paniculata) under natural and experimental field conditions. Biol Agric Hortic 34:173-185. https://doi.org/10.1080/014465.2017.1408492

3. Ekka PA, Rastogi N, Singh H, Singh HB, Ray S (2020) Lycaenid-tending ants can contribute to fitness gain of the infested host plants by providing nutrients. Arthropod Plant Interact 14:745-757. https://doi.org/10.1007/s11829-020-09785-2

4. Glick BR (2012) Plant growth-promoting bacteria: mechanisms and applications. Scientifica, 963401

5. Lugtenberg B, Kamilova F (2009) Plant-growth-promoting rhizobacteria. Annu Rev Microbiol 63:541-556. https://doi.org/10.1146/annurev.micro.62.081307.162918

6. Prusty R, Grisafi P, Fink GR (2004) The plant hormone indoleacetic acid induces invasive growth in Saccharomyces cerevisiae. PNAS 101:4153-4157. https:// doi.org /10. 1073/ pnas.0 400659101

7. Illmer P, Barbato A, Schinner F (1995) Solubilization of hardly-soluble AlPO4 with P-solubilizing microorganisms. Soil Biol Biochem 27:265-270. https://doi.org/10.1016/0038-0717(94)00205-F

8. Richardson AE (2001) Prospects for using soil microorganisms to improve the acquisition of phosphorus by plants. Funct Plant Biol $28: 897-906$. https://doi.org/10.1071/PP01093

9. Vessey JK (2003) Plant growth-promoting rhizobacteria as biofertilizers. Plant soil 255:571-586. https://doi.org/10.1023/A:1026037216893

10. Kloepper JW (1992) Plant growth-promoting rhizobacteria as biological control agents. In: Metting FB (ed) Soil Microbial Ecology. Marcel Dekker, New York, pp 255-274

11. Babalola $\mathrm{OO} \mathrm{(2010)} \mathrm{Beneficial} \mathrm{bacteria} \mathrm{of} \mathrm{agricultural} \mathrm{importance.} \mathrm{Biotechnol} \mathrm{Lett} \mathrm{32:15591570.} \mathrm{https://doi.org/10.1007/s10529-010-0347-0}$

12. Kim JT, Kim SD (2008) Suppression of bacterial wilt with Bacillus subtilis SKU48-2 strain. Microbio Biotec Lett 36:115-120

13. Backer R, Rokem JS, llangumaran G, Lamont J, Praslickova D, Ricci E, Subramanian S, Smith DL (2018) Plant growth-promoting rhizobacteria: context, mechanisms of action, land roadmap to commercialization of biostimulants for sustainable agriculture. Front Plant Sci 9:1473-1504. https://doi.org/10.3389/fpls.2018.01473

14. Ramamoorthy V, Viswanathan R, Raguchander T, Prakasam V, Samiyappan R (2001) Induction of systemic resistance by plant growth promoting rhizobacteria in crop plants against pests and diseases. Crop Prot 20:1-11. https://doi.org/10.1016/S0261-2194(00)00056-9

15. Rajput RS, Singh J, Singh P, Vaishnav A, Singh HB (2020) Influence of Seed Biopriming and vermiwash treatment on tomato plant's immunity and nutritional quality upon Sclerotium rolfsii challenge inoculation. J Plant Growth Regul 1-17. https://doi.org/10.1007/s00344-020-10205-1

16. Alori ET, Babalola $O O$ (2018) Microbial inoculants for improving crop quality and human health in Africa. Front Microbiol 9:2213-2225. https://doi.org/10.3389/fmicb.2018.02213

17. Lindström S, Timonen S, Sundström L, Johansson H (2019) Ants reign over a distinct microbiome in forest soil. Soil Biol Biochem 139:107529107568. https://doi.org/10.1016/j.soilbio.2019.107529

18. Cesarano G, Filippis FD, Storia AL, Scala F, Bonanomi G (2017) Organic amendment type and application frequency affect crop yields, soil fertility and microbiome composition. Appl Soil Ecol 120:254-264. https://doi.org/10.1016/j.apsoil.2017.08.017

19. Shukla RK, Singh H, Rastogi N, Agarwal VM (2013) Impact of abundant Pheidole ant species on soil nutrients in relation to the food biology of the species. Appl Soil Ecol 71:15-23. https://doi.org/10.1016/j.apsoil.2013.05.002

20. Czaczkes TJ, Heinze J, Ruther J (2015) Nest etiquette-where ants go when nature calls. PLoS One 10:1-8. https://doi.org/10.1371/journal.pone.0118376

21. Offenberg J, Damgaard C (2019) Ants suppressing plant pathogens: a review. Oikos128:1691-1703. https://doi.org/10.1111/oik.06744

22. Wagner D, Jones JB, Gordon DM (2004) Development of harvester ant colonies alters soil chemistry. Soil Biol Biochem 36:797-804<uverticalalign:super;>.</uvertical-align:super;><uvertical-align:super;>. https://doi.org/10.1016/j.soilbio.2004.01.009</uvertical-align:super;\&gt

23. Bharti H, Guénard B, Bharti M, Economo EP (2016) An updated checklist of the ants of India with their specific distributions in Indian states (Hymenoptera, Formicidae). ZooKeys 551:1-83. https://doi.org/10.3897/zookeys.551.6767

24. Andersen AN (2000) The ants of northern Australia: a guide to the monsoonal fauna. CSIRO Publishing, Collingwood

25. Sagar S, Biswas DK, Singh A (2020) Genomic and expression analysis indicate the involvement of phospholipase $C$ family in abiotic stress signaling in chickpea (Cicer arietinum). Gene 7 53: 144797-144808. https://doi.org/10.1016/j.gene.2020.144797 
26. Javaid A, Khan IH (2016) Management of collar rot disease of chickpea by extracts and soil amendment with dry leaf biomass of Melia azedarach L. Phil. Agric Sci 99:150-155

27. Tarafdar A, Rani TS, Chandran USS, Chobe DR, Sharma M (2018) Exploring combined effect of abiotic (soil moisture) and biotic (Sclerotium rolfsii Sacc.) stress on collar rot development in chickpea. Front Plant Sci 9:1154-1167. https://doi.org/10.3389/fpls.2018.01154

28. Ram RM, Rajput RS, Vaishnav A (2020) Management of Sclerotium rolfsii induced diseases in crops by Trichoderma Species. In: Sharma SK, Singh UB, Sahu PK, Singh HV, Sharma PK (eds) s Rhizosphere Microbes. Springer, Singapore, pp 201-215

29. Mehta S, Nautiyal CS (2001) An efficient method for qualitative screening of phosphate-solubilizing bacteria. Curr Microbiol 43:51-56. https://doi.org/10.1007/s002840010259

30. Nautiyal CS (1999) An efficient microbiological growth medium for screening phosphate solubilizing microorganisms. FEMS Microbiol Lett 170:265-270. https://doi.org/10.1016/s0378-1097(98)00555-2

31. Bric JM, Bostock RM, Silverstone SE (1991) Rapid in situ assay for indole acetic acid production by bacteria immobilized on a nitrocellulose membrane. Appl Environ Microbiol 57:535-538. https://doi.org/10.1128/aem.57.2.535-538.1991

32. Salkowski E (1885) Ueber das verhalten der skatolcarbonsäure im organismus. Z Phys Chem 9:23-33. https://doi.org/10.1515/bchm1.1885.9.1.23

33. Bano N, Musarrat J (2003) Characterization of a new Pseudomonas aeruginosa strain NJ-15 as a potential biocontrol agent. Curr Microbiol 46:324328. https://doi.org/10.1007/s00284-002-3857-8

34. Flores-Moctezuma HE, Montes-Belmont R, Jimenez-Perez A, Nava-Juarez R (2006) Pathogenic diversity of Sclerotium rolfsii isolates from Mexico, and potential control of southern bight through solarization and organic amendments. Crop Prot 25:195-201. https://doi.org/10.1016/j.cropro.2005.04.007

35. Maurya MK, Singh R, Tomer A (2014) In vitro evaluation of antagonistic activity of Pseudomonas fluorescens against fungal pathogen. J Biopestic 7:43-46

36. Jain A, Singh A, Singh S, Singh HB (2013) Microbial consortium induced changes in oxidative stress markers in pea plants challenged with Sclerotinia sclerotiorum. J Plant Growth Regul 32:388-398. https://doi.org/10.1007/s00344-012-9307-3

37. Yadav SK, Dave A, Sarkar A, Singh HB, Sarma BK (2013) Co-inoculated biopriming with Trichoderma, Pseudomonas and Rhizobium improves crop growth in Cicer arietinum and Phaseolus vulgaris. Int J Agric Environ Biotechnol 6:255-259

38. Sarma BK, Basha SA, Singh DP, Singh UP (2007) Use of non-conventional chemicals as an alternative approach to protect chickpea (Cicer arietinum) from Sclerotinia stem rot. Crop Prot 26:1042-1048. https://doi.org/10.1016/j.cropro.2006.09.015

39. Wilson K (1987) Preparation of genomic DNA from bacteria. Curr Protoc Mol Biol 2:1-5. https://doi.org/10.1002/0471142727.mb0204s56

40. Tonelli ML, Furlan A, Taurian T, Castro S, Fabra A (2011) Peanut priming induced by biocontrol agents. Physiol Mol Plant Pathol 75:100-105. https://doi.org/10.1016/j.pmpp. 2010.11.0 01

41. Singh P, Singh J, Ray S, Rajput RS, Vaishnav A, Singh RK, Singh HB (2020) Seed biopriming with antagonistic microbes and ascorbic acid induce resistance in tomato against Fusarium wilt. Microbiol Res 237:126482. https://doi.org/10.1016/j.micres.2020.126482

42. Zhao P, Li P, Wu S, Zhou M, Zhi R, Gao H (2019) Volatile organic compounds (VOCs) from Bacillus subtilis CF-3 reduce anthracnose and elicit active defense responses in harvested litchi fruits. AMB Express 9:1-13. https://doi.org/10.1186/s13568-019-0841-2

43. Radhakrishnan R, Hashem A, Abd-Allah EF (2017) Bacillus: a biological tool for crop improvement through bio-molecular changes in adverse environments. Front Physiol 8:667-681. https://doi.org/10.3389/fphys.2017.00667

44. Kerff F, Amoroso A, Herman R, Sauvage E, Petrella S, Filée P, Cosgrove DJ (2008) Crystal structure and activity of Bacillus subtilis YoaJ (EXLX1), a bacterial expansin that promotes root colonization. PNAS 105:16876-16881. https://doi.org/10.1073/pnas.0809382105

45. Weng J, Wang Y, Li J, Shen Q, Zhang R (2013) Enhanced root colonization and biocontrol activity of Bacillus amyloliquefaciens SQR9 by abrB gene disruption. Appl Microbiol Biot echnol 97:8823-8830. https://doi.org/10.1007/s00253-012-4572-4

46. Chen L, Heng J, Qin S, Bian K (2018) A comprehensive understanding of the biocontrol potential of Bacillus velezensis LM2303 against Fusarium head blight. PLoS One 13:1-22. https://doi.org/10.1371/journal.pone.0198560

47. Brown ME (1968) Production of plant growth substances by. Azotobacter chroococcum Microbiol 53:135-144. https://doi.org/10.1099/0022128753-1-135

48. Fravel DR (2005) Commercialization and implementation of biocontrol. Annu Rev Phytopathol 43:337-359. https://doi.org/10.1146/annurev.phyto.43.032904.092924

49. Lim SM, Yoon MY, Choi GJ, Choi YH, Jang KS, Shin TS, Park HW, Yu NH, Kim YH, Kim JC (2017) Diffusible and volatile antifungal compounds produced by an antagonistic Bacillus velezensis G341 against various phytopathogenic fungi. J Plant Pathol 33:488-498. https://doi.org/10.5423/PPJ.OA. 04.2017.0073

50. Cao Y, Pi H, Chandrangsu P, Li Y, Wang Y, Zhou H, Xiong H, Helmann JD, Cai Y (2018) Antagonism of two plant-growth-promoting Bacillus velezensis isolates against Ralstonia solanacearum and Fusarium oxysporum. Sci Rep 8:1-14. https://doi.org/10.1038/s41598-01822782-z

51. Little AE, Murakami T, Mueller UG, Currie CR (2006) Defending against parasites: fungus-growing ants combine specialized behaviors and microbial symbionts to protect their fungus gardens. Biol lett 2:12-16. https://doi.org/10.1098/rsbl.2005.0371

52. Chen K, Huang LL, Xu CF (2013) Molecular characterization of the enzymes involved in the degradation of a brominated aromatic herbicide. Mol Microbiol 89:1121-1139. https://doi.org/10.1111/mmi.12332

Page $12 / 14$ 
53. Kim JM, Le NT, Chung BS, Park JH, Bae JW, Madsen EL, Jeon CO (2008) Influence of soil components on the biodegradation of benzene, toluene, ethylbenzene, and o-, m-, and p-xylenes by the newly isolated bacterium Pseudoxanthomonas spadix BD-a59. Appl Environ Microbiol 74:7313-7320. https://doi.org/10.1128/AEM.01695-08

\section{Figures}

A

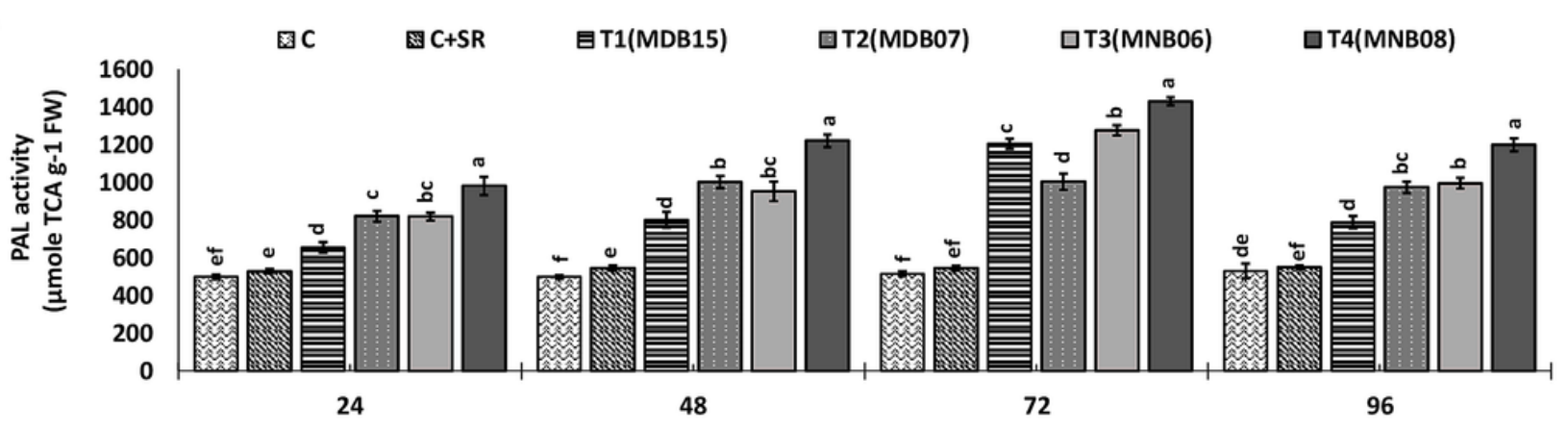

B

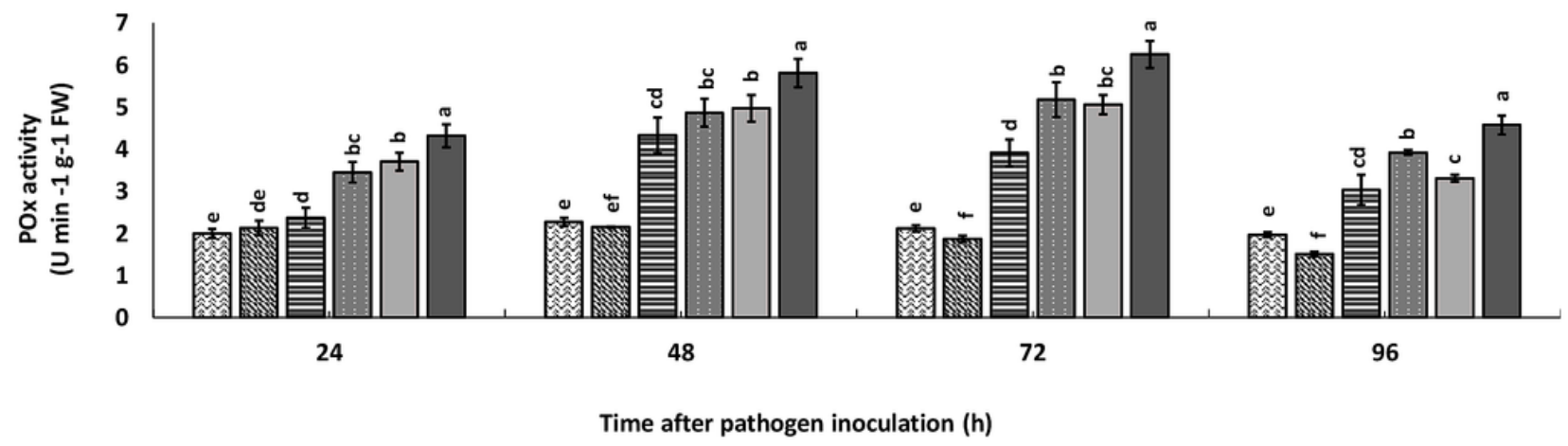

Figure 1

Activities of two enzymes: phenylalanine ammonia-lyase recorded as $\mu \mathrm{M}$ TCA (trans-cinnamic acid) $\mathrm{g}^{-1}$ fresh weight (FW) (A) and, of polyphenol-oxidase recorded as $\mathrm{U} \mathrm{min}^{-1} \mathrm{~g}^{-1} \mathrm{FW}(\mathrm{B})$ at intervals of $24 \mathrm{~h}, 48 \mathrm{~h}, 72 \mathrm{~h}$, and $96 \mathrm{hrs}$, in chickpea plants, germinated from bioprimed seeds with bacterial treatments (T): T1 (MDB15), T2 (MDB07), T3 (MNB06), and T4 (MNB08), and challenged with Sclerotium rolfsii. The two controls were: C (no treatment and S. rolfsii) and C + SR (control with $S$. rolfsii). Results are expressed as means of five replicates, and vertical bars indicate standard deviations of the means. Different letters indicate significant differences among treatment results taken at the same time interval according to Duncan's multiple range test at $\mathrm{p} \leq$ 0.05 . 


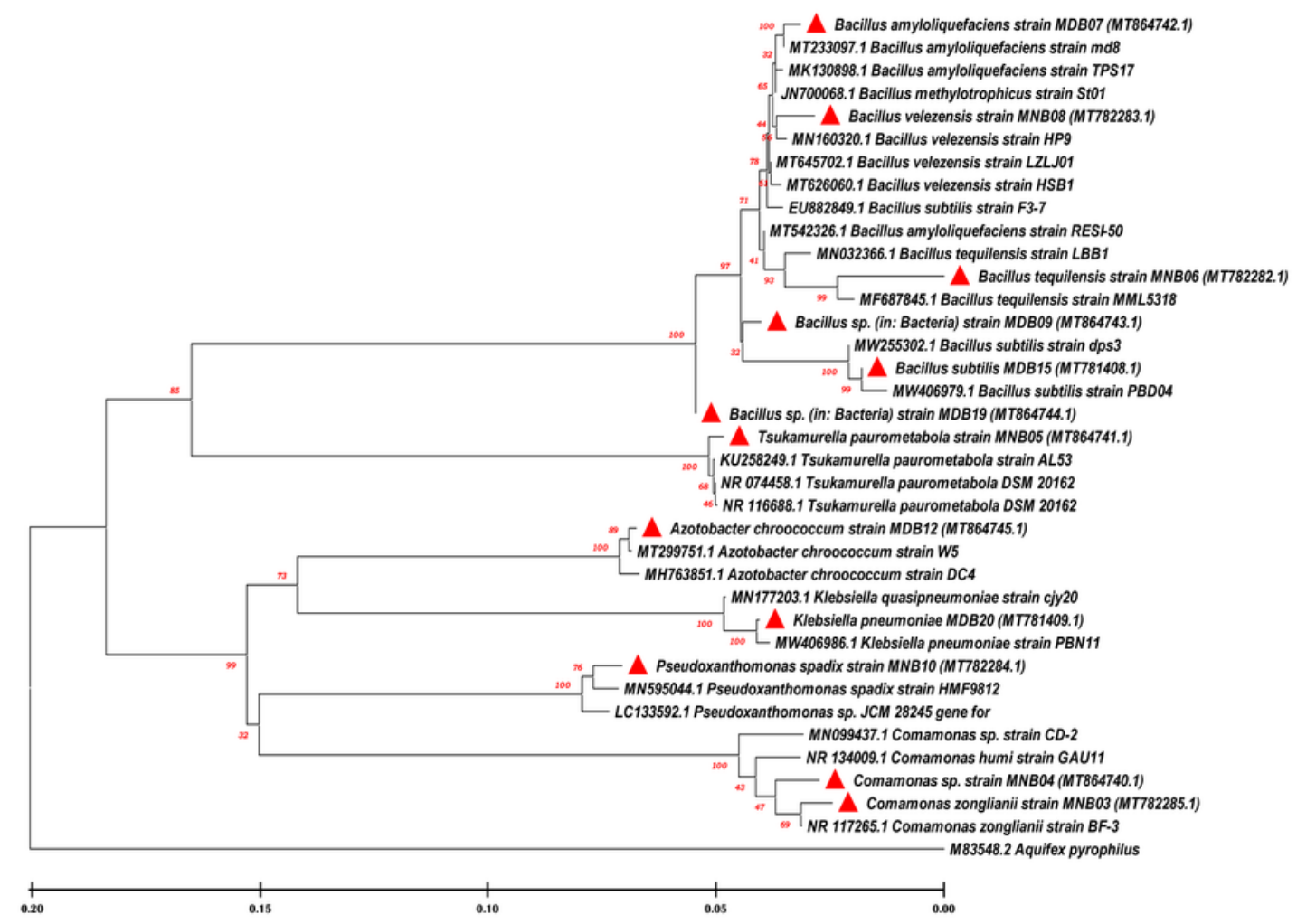

Figure 2

Phylogenetic analysis of 16 s rRNA partial sequences for isolated PGPB, with neighbour joining method of phylogeny and 1000 bootstrap replications. The sequences isolated PGPB submitted to NCBI GenBank are highlighted with red color symbol, with their respective Accession number. The scale bar represents evolutionary distance.

\section{Supplementary Files}

This is a list of supplementary files associated with this preprint. Click to download.

- Supplementarydata.docx 